\title{
Effect of Selected Microenvironmental Factors on Colony Growth and Cross Infectional Ability of Fungal Pathogens Causing Root Rot Disease of Jak (Artocarpus heterophillus)
}

\author{
M. Kuruppu, D. M. De. Costa ${ }^{1 *}$ and T.H.P.S. Fernando ${ }^{2}$ \\ Fruit Research and Development Institute \\ Horana, Sri Lanka
}

\begin{abstract}
Root diseases have become an emerging biotic threat to Jak (A. heterophillus), grown in Sri Lanka. Isolation of the causal agents, identification and determination of the effect of selected microenvironmental factors and the crossinfection ability of the causal agents on other perennial crops towards development of effective management measures were the objectives of the present study. Two Rigidoporous microspores isolates and a Fusarium oxysporum and a F. solani isolate were identified as causal agents of root rot disease of Jak. Colony growth of the two $R$. microsporus isolates and the Fusarium isolates responded differently to $\mathrm{pH}$, temperature and light intensity. Differences of colony growth responses were identified even between the two isolates of R. microporus. Among the perennial tree species used, Atocarpus nobilis was highly susceptible to all four fungal isolates and the lowest infection ability was shown on Persea americana. Artocarpus altilis (Rata Del), Hevea brasiliensis (Rubber), Cinnammomum zeylanicum (Cinnamon), Durio zibethinus (Durian), Psidium guajava (Guvava) and Nephellium lapaceum (Rambutan)were equally-susceptible to the infection by the four fungal isolates, used. Findings of the study are informative when developing an integrated management programme against root diseases of Jak.
\end{abstract}

Keywords: Colony growth response, Fusarium oxysporum, Fusarium solani, Rigidoporus microporus

\section{INTRODUCTION}

Jak (Artocarpus heterophillus), belonging to Family Moraceae, is an economically versatile tropical tree crop, providing food, timber, fuel, fodder and medicinal and industrial products. Despite the multi-purpose advantages of Jak tree, it is an underutilized crop in most of the Asian countries (Nair et al., 2018), and Sri Lanka is not an exception. In Sri Lanka, the tree is grown as a home garden crop along with

\footnotetext{
${ }^{1}$ Department of Agricultural Biology, Faculty of Agriculture, University of Peradeniya, Sri Lanka

2 Rubber Research Institute, Dartonfield, Agalawatta, Sri Lanka

* Corresponding author: devikadecosta@gmail.com
} 
other perennial trees or naturally exists in forests. Although the economic value of the crop has been well-recognized, very limited research has been done on different aspects of the crop including management of diseases. From the recent past, wilting, gradual decline and the death of the tree are frequent complaints made by owners of Jak trees in Sri Lanka. Field observations based on symptomatology have revealed that such trees are infected with root diseases. However, causal agents of the root diseases of Jak and management measures, effective against the causal agents have not been investigated in detail.

Decline of Jak tree has been reported in Vietnam and Philippines and Phytophthora palmivora has been identified as the causal organism (Tri et al., 2015; Borines et al., 2014), where chlorosis, wilting, defoliation, trunk cankers and tree death are the symptoms. Artocarpus nobilis, an endemic tree grown in homesteads of Sri Lanka, shows leaf discoloration, leaf fall and die back of affected shoots along with the formation of rhizomorphs on roots and on the collar region (Madushani et al., 2013). The disease has been identified as white root disease caused by Rigidoporus microporus, the causal agent of the same disease of rubber (Hevea brasiliensis). Limited literature available on Jak root diseases shows that taxonomically-diverse fungi (e.g. Basidiomycota, Oomycota, Ascomycota) are responsible for the root diseases of Jak and taxonomically-related tree species. Hence, management measures have to be developed strategically and holistically to solve the issues of Jak diseases in Sri Lanka.

The objectives of the present study were to identify causal agents of root diseases of Jak and determine the effect of selected microenvironmental factors on growth of the causal agents along with its cross infectional ability on several other perennial trees. Findings of the present study can be used to develop measures effective of integrated management of root diseases of Jak.

\section{MATERIALS AND METHODS}

\section{Identification of Fungal Pathogens}

Root pieces excised from root rot infected Jak trees were wrapped in moist newspapers till rhizomorphs were developed. Sections of rhizomorphs were transferred aseptically to PDA plates and cultures were purified by dilution plate technique. Fungi isolated onto PDA were purified by subculturing and dilution plate technique. Well separated fungal colonies were cultured for seven days and subjected to genomic DNA extraction. Briefly, a mycelial mass from an area of $1 \mathrm{~cm}^{2}$ was mixed with $500 \mu \mathrm{l}$ of SDS extraction buffer (Arnold and Lutzoni, 2007) and ground thoroughly with a sterile pipette tip. An aliquot of $500 \mu \mathrm{l}$ of phenol:chloroform:isoamyl alcohol (25:24:1) was added and mixed gently by inverting. The mixture was centrifuged at $12000 \mathrm{rpm}$ for $15 \mathrm{~min}$ and DNA was precipitated with ice-cold isopropanol and centrifuged at $12000 \mathrm{rpm}$ for $3 \mathrm{~min}$. Pellet was washed with $70 \%$ ethanol at 12000 
rpm for $3 \mathrm{~min}$. The supernatant was discarded and the air-dried DNA pellet was mixed with $25 \mu$ l of ultrapure water.

\section{PCR amplification, DNA sequencing and Homology search}

Genomic fungal DNA (50 ng) was used for PCR amplification with ITS1 (5'TCC GTA GGT GAA CCT GCG G3') and ITS4 (5'TCC TCC GCT TAT TGA TAT GC3') primers (White et.al.,1990) and the PCR conditions were programmed for 35 cycles, each cycle having a denaturation step at $94^{\circ} \mathrm{C}$ for $30 \mathrm{sec}$, annealing at $49^{\circ} \mathrm{C}$ for $30 \mathrm{sec}$ and extension at $72{ }^{\circ} \mathrm{C}$ for $1 \mathrm{~min}$ and a final elongation step at $72{ }^{\circ} \mathrm{C}$ for $5 \mathrm{~min}$. PCR products were subjected to gel electrophoresis. Then they were subjected to DNA sequencing (Macrogen, Korea) and homology search were done (BLAST, NCBI). 492 $\mathrm{bp}$ and $500 \mathrm{bp}$ band size were shown in two isolates of Rigidoporus microporus 550 bp and 570bp (8F and 9T) were shown in F.solani and F.oxysporum (K3 and B1) respectively.

\section{Confirmation of Pathogenicity}

After identification of the purified fungal isolates (Rigidoporus microporus, Fusarium solani and $F$. oxysporum) by molecular methods, pathogenicity was confirmed according to standard Koch's postulates. Pathogenicity of Rigidoporus isolates was confirmed according to the method followed by Fernando et al. (2012). Briefly, autoclaved mature Jak root pieces $(10 \mathrm{~cm}$ in length) were inoculated with Rigidoporus isolates, separately and the root pieces were kept at room temperature in a humid chamber till the development of rhizomorphs. Thereafter, the root pieces were buried in sterilized soil containing plastic containers at a depth of $5 \mathrm{~cm}$. Three months old Jak seedlings, exposed to water deficit conditions for $24 \mathrm{hr}$ were planted in the pots containing the Rigidoporus-inoculated root pieces. Collar region of three months old seedlings were rubbed by a sand paper and $0.7 \mathrm{~cm}$ mycelia discs of both Fusarium species were placed on partially wounded area of collar region with moistened cotton wool. Seedlings were kept in a plant propagator for one month. Each fungal pathogen isolate was replicated with 10 seedlings. After observing the wilt symptoms in Jak seedlings, root pieces of the seedlings were used for isolation of the pathogen onto PDA medium. Fungal colonies re-isolated from the infected-Jak seedlings were subjected to PCR using ITS1 and ITS4 primers. PCR products were sent for DNA sequencing (Macrogen, Korea) and DNA homology search was done for confirmation of the identity of the re-isolated fungi.

\section{Effect of Temperature, pH and Light Intensity on Colony Growth of Fungal Isolates}

Among the identified fungal isolates, two $R$. microporus isolates and $F$. oxysporum and F.solani isolates were used to determine the effect of several selected microenvironmental parameters (i.e. temperature, $\mathrm{pH}$ and light intensity) on the colony growth of fungi. Initially, a suitable medium for culturing all above four fungal isolates was selected using potato dextrose agar (PDA), Lima bean agar (LBA) and 
malt extract agar (MEA) as an observational study. Based on colony growth rate, LBA was determined to be the most suitable medium for culturing the four fungal isolates in vitro. To determine the effect of $\mathrm{pH}, \mathrm{LBA}$ was adjusted from $\mathrm{pH} 4-11$ using diluted $\mathrm{NaOH}$ or $\mathrm{HCl}$ and eight separate experiments were conducted for the four fungal isolates to check the effect of each $\mathrm{pH}$ level with 10 replicates per isolate. Temperature effect was determined by exposing the fungal isolates grown on LBA to $15^{\circ} \mathrm{C}, 20^{\circ} \mathrm{C}$, $25^{\circ} \mathrm{C}$ and $30^{\circ} \mathrm{C}$ using a temperature controlled incubator. Separate experiments were conducted to check each temperature effect using 10 replicates per fungal isolate. Fungal cultures were exposed to three light intensities (normal light conditions (0.6 lux), diffused light conditions (0.05 lux) and dark conditions (0 lux) as three seperate experiments with 10 replicates per each isolate. In all experiments, treatments were arranged according to a complete randomized design. Colony growth was measured at two day intervals.

\section{Determination of the Cross Infection Ability of Fungal Pathogens of Jak}

Artocarpus nobilis (Wal Del), Artocarpus altilis (Rata Del), Hevea brasiliensis (Rubber), Cinnammomum zeylanicum (Cinnamon), Durio zibethinus (Durian), Psidium guajava (Guvava), Nephellium lapaceum (Rambutan) and Persea americana (Avocado) were selected as the host crops to check the cross infection ability of the four fungal isolates. Root pieces (approximately $15 \mathrm{~cm}$ in length and $5 \mathrm{~cm}$ of diameter) from above tree species were surfaced sterilized with teepol, following $20 \%$ sodium hipochloride aqueous solution and rinsed with running tap water for $30 \mathrm{~min}$. Then the root pieces were aseptically inoculated with $1 \mathrm{~cm}$ discs of each fungal isolate. Separate experiments were carried out according to a complete randomized design with 5 replicates for each host species. These artificially-inoculated root pieces were placed in a humid chamber for a period of one week and the lesion length was measured at two day intervals. From inoculated root pieces of each host plant, pathogen was reisolated. Confirmation of $F$. solani and $F$. oxysporum cultures were done based on colony and spore morphology. Colonies of the fungal isolates were subjected to DNA extraction, PCR amplification, DNA sequencing and homology search for confirmation of identity.

\section{RESULTS}

\section{Identification of Fungal Pathogens}

Four purified fungal cultures which showed distinct colony morphology were identified by molecular methods and the details are given in Table 1. 
Table 1. Identity of fungal isolates based on DNA homology search.

\begin{tabular}{llllll}
\hline $\begin{array}{l}\text { Code of } \\
\text { fungal } \\
\text { isolate }\end{array}$ & $\begin{array}{l}\text { Description of the best } \\
\text { homologue }\end{array}$ & $\begin{array}{l}\text { Query } \\
\text { cover } \\
(\%)\end{array}$ & $\begin{array}{l}\text { E- } \\
\text { value }\end{array}$ & $\begin{array}{l}\text { Identity } \\
(\%)\end{array}$ & $\begin{array}{l}\text { Accession } \\
\text { number }\end{array}$ \\
\hline R1 & $\begin{array}{l}\text { Rigidoporusmicroporus } \\
\text { SEG }\end{array}$ & 88 & 0 & 99 & MG199553.1 \\
R8 & $\begin{array}{l}\text { Rigidoporusmicroporus } \\
\text { PM52 }\end{array}$ & 30 & 0 & 99 & KX090082.1 \\
B1 & $\begin{array}{l}\text { Fusariumoxysporum } \\
\text { F102 }\end{array}$ & 85 & 0 & 95 & KJ512160.1 \\
K3 & Fusarium solani 21019 & 28 & 0 & 97 & KY348699.1 \\
\hline
\end{tabular}

Isolate $\mathrm{R} 1$, can be identified as $R$. microporus, as it gave the best match with $R$. microporus SEG isolate with a $88 \%$ query cover, 0.00 E-value and $99 \%$ identity (Table 1). Similarly, isolate B1 can be identified as Fusarium oxysporum as it gave $85 \%$ query cover, 0.00 E-value and $95 \%$ identity with $F$. oxysporum $\mathrm{F} 102$ isolate. Though, isolate K3 gave a $28 \%$ query cover with a 0.00 E-value and a $97 \%$ identity, spore morphology clearly showed the presence of macro and micro conidia unique to Fusarium spp.(Figure 1), hence the isolate $\mathrm{K} 3$ can be considered as $F$. solani. R8 isolate gave the best match with $R$. microporus, but with a 0.00 E-value and a $99 \%$ identity, but with a $30 \%$ query cover.

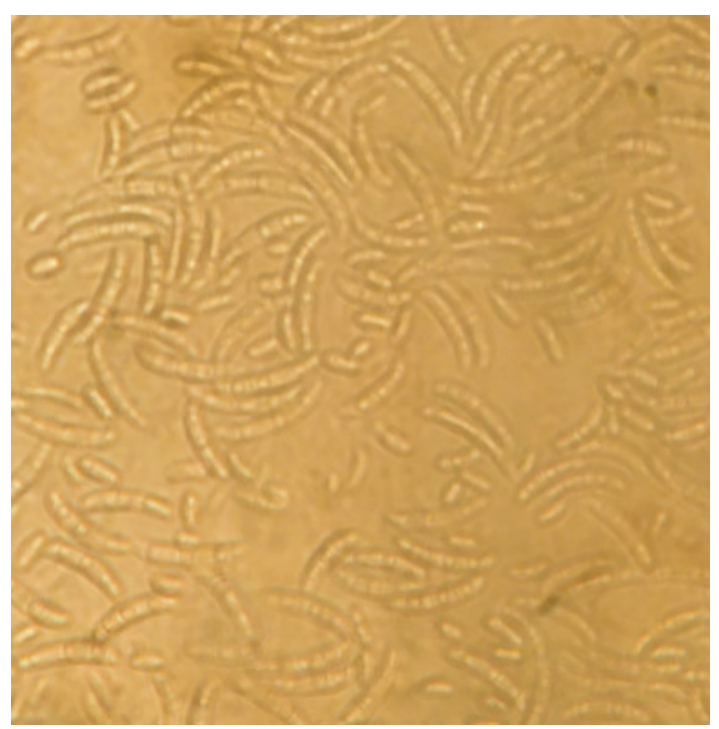

Figure 1. Macro (sickle-shaped conidia) and micro (small and oval shaped) conidia of fungal isolate $\mathrm{K3}$ (magnification $\mathrm{x} 400$ ). 


\section{Confirmation of Pathogenicity}

Table 2. Percentage of Jak seedlings showed symptoms of above ground parts one month after inoculation of the four fungal isolates.

\begin{tabular}{|c|c|c|c|}
\hline Treatment & $\begin{array}{ll} & \text { rhizomorphs } \\
\text { on root } & \text { rurface }\end{array}$ & Symptom observed & $\begin{array}{l}\text { Symptoms in } \\
\text { above ground } \\
\text { parts }\end{array}$ \\
\hline Control & 0 & No symptoms in above ground parts & 0 \\
\hline Isolate R1 & 100 & $\begin{array}{l}\text { Wilting and discoloured roots when split } \\
\text { opened }\end{array}$ & it 1 \\
\hline Isolate R8 & 100 & $\begin{array}{l}\text { Wilting and discoloured roots when split } \\
\text { opened }\end{array}$ & it 1 \\
\hline Isolate B1 & - & $\begin{array}{l}\text { Leaf yellowing and discoloration of collar } \\
\text { region in longitudinal section of stem, } \\
\text { Penetration of lesion in to outer layer of the } \\
\text { seedlings, discoloured roots when split opened }\end{array}$ & $\begin{array}{ll}r & 2 \\
\text { e } & \\
d & \end{array}$ \\
\hline K3 & - & $\begin{array}{l}\text { Leaf yellowing and discoloration of collar } \\
\text { region in longitudinal section of stem, } \\
\text { penetration of lesion in to outer layer of the } \\
\text { seedlings }\end{array}$ & ir \\
\hline
\end{tabular}

Rhizomorphs could be observed in the roots of Rigidoporous-inoculated seedlings. Above ground symptom development was very slow in Jak seedlings, even after onemonth period.

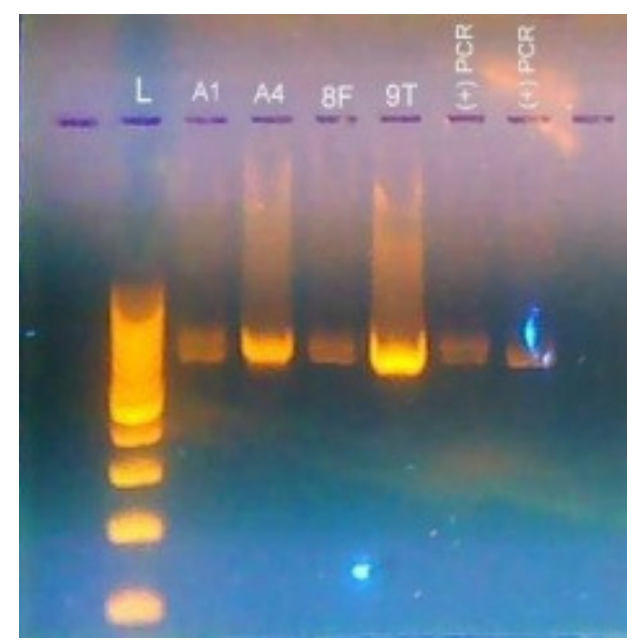

Plate 1. Visualization of PCR products of Rigidoporus isolates performed on $2 \%$ agarose gel. $\mathrm{L}=100 \mathrm{bp}$ ladder, $8 \mathrm{~F}$ and $9 \mathrm{~T}=$ Rigidoporus microporus isolated from jack trees, A1- Rigidoporus microporus isolated from $\boldsymbol{H}$. brasiliensis, A4- Rigidoporus microporus isolated from $C$. zeylanicum $(+) \mathbf{P C R}=$ positive control. 


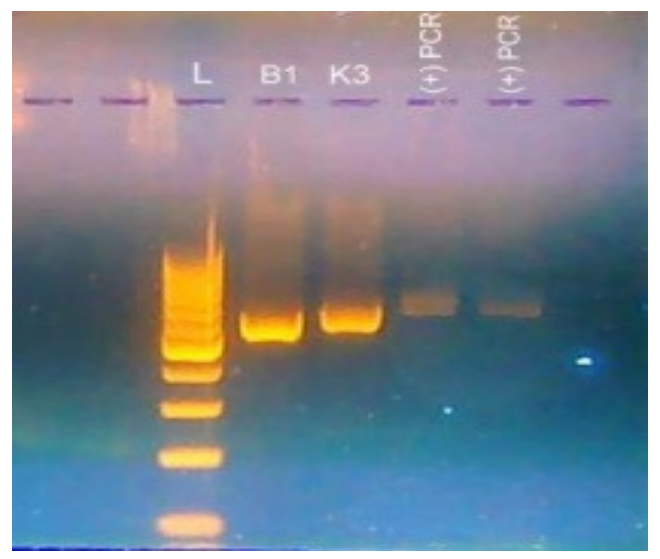

Plate 2. Visualization of PCR products of Fusarium isolates performed on 2\% agarose gel. Notes: $\mathrm{L}=100 \mathrm{bp}$ ladder, $\mathrm{B} 1=$ Fusarium oxysporum, $\mathrm{K3}=$ Fusarium solani, $(+) \mathrm{PCR}=$ positive control.

\section{Effect of pH, Temperature and Light Intensity on Growth of Fungal Isolates}

pH 6 has resulted in the highest colony diameter for Rigidoporus microporus both isolates and Fusarium oxysporum isolate. F. solani isolate has grown best when the $\mathrm{pH}$ of the medium was 4.0. All four fungal isolates showed the best colony growth at normal light and diffused light conditions, and there was no significant difference on the colony diameter between the two light intensity levels (Table 4). However, $R$. microporus SEG1 isolate showed equal colony growth under all light intensities (even under dark conditions).

Table 3. Effect of the pH of culture medium on colony growth of Rigidoporus and Fusarium isolates.

\begin{tabular}{lllll}
\hline & & \multicolumn{3}{c}{ Mean colony diameter $(\mathrm{cm})$} \\
pH & R.microporusSEG1 & R.microporusPM52 & F. solani & F.oxysporum \\
\hline pH 4 & $4.22^{\text {ba }}$ & $4.52^{\mathrm{b}}$ & $4.48^{\mathrm{a}}$ & $4.27^{\mathrm{b}}$ \\
pH 5 & $4.4^{\mathrm{ba}}$ & $4.37^{\mathrm{b}}$ & $4.04^{\mathrm{b}}$ & $5.38^{\mathrm{a}}$ \\
pH 6 & $4.58^{\mathrm{a}}$ & $4.77^{\mathrm{a}}$ & $4.02^{\mathrm{b}}$ & $5.5^{\mathrm{a}}$ \\
pH 7 & $3.17^{\mathrm{b}}$ & $3.32^{\mathrm{d}}$ & $3.31^{\mathrm{c}}$ & $3.7^{\mathrm{c}}$ \\
pH 8 & $3.27^{\mathrm{b}}$ & $3.41^{\mathrm{d}}$ & $3.2^{\mathrm{c}}$ & $3.94^{\mathrm{c}}$ \\
pH 9 & $2.84^{\mathrm{c}}$ & $3.71^{\mathrm{c}}$ & $3.37^{\mathrm{c}}$ & $3.55^{\mathrm{c}}$ \\
pH 10 & $3.22^{\mathrm{b}}$ & $3.73^{\mathrm{c}}$ & $3.16^{\mathrm{d}}$ & $2.84^{\mathrm{d}}$ \\
pH 11 & $2.08^{\mathrm{e}}$ & $2.51^{\mathrm{e}}$ & $2.54^{\mathrm{e}}$ & $1.39^{\mathrm{e}}$ \\
CV\% & 2.03 & 2.03 & 2.03 & 2.03 \\
LSD & 1.78 & 0.24 & 0.88 & 0.31 \\
\hline
\end{tabular}

Means with the same letter along the column are not significantly different at $\mathrm{P}=0.05$ 
Table 4. The effect of different light intensities on colony growth of $R$. microporus isolates and Fusarium isolates.

\begin{tabular}{|c|c|c|c|c|}
\hline & \multicolumn{4}{|c|}{ Mean colony diameter $(\mathrm{cm})$} \\
\hline Light intensity (lux) & $\begin{array}{l}\text { R.microporus } \\
\text { SEG1 }\end{array}$ & $\begin{array}{l}\text { R.microporus } \mathrm{P} \\
\text { M52 }\end{array}$ & F. solani & F.oxysporum \\
\hline Normal light (0.6) & $4.97^{\mathrm{a}}$ & $5.77^{\mathrm{a}}$ & $4.92^{\mathrm{a}}$ & $5.63^{\mathrm{a}}$ \\
\hline Diffuse light (0.05) & $4.9^{\mathrm{a}}$ & $5.63^{\mathrm{a}}$ & $4.87^{\mathrm{a}}$ & $5.43^{\mathrm{a}}$ \\
\hline $\begin{array}{ll}\text { Fully } & \text { dark } \\
\text { condition }(0) & \end{array}$ & $4.78^{\mathrm{a}}$ & $5.01^{\mathrm{b}}$ & $4.36^{\mathrm{b}}$ & $4.82^{b}$ \\
\hline $\mathrm{CV} \%$ & 2.17 & 2.17 & 2.17 & 2.17 \\
\hline LSD & 0.16 & 0.4 & 0.33 & 0.42 \\
\hline
\end{tabular}

Means with the same letter along the column are not significantly different at $P=0.05$

The two $R$. microporus isolates showed the highest colony growth at $25{ }^{\circ} \mathrm{C}$ and the Fusarium isolates had the best growth at $30^{\circ} \mathrm{C}$ (Table 5) six days after incubation. In general, all four fungal isolates had the highest colony growth between $25-30{ }^{\circ} \mathrm{C}$. When the temperature increased to $35^{\circ} \mathrm{C}$, all isolates except Fusarium oxysporum showed a drastic reduction of the colony growth.

Table 5. The effect of different temperature on colony growth of $\boldsymbol{R}$. microporus and Fusarium isolates

\begin{tabular}{lllll}
\hline & \multicolumn{4}{c}{ Mean colony diameter $(\mathrm{cm})$} \\
\hline $\begin{array}{l}\text { Temperature } \\
\left({ }^{\circ} \mathrm{C}\right)\end{array}$ & R.microporusSEG1 & R.microporusPM52 & F. solani & F.oxysporum \\
\hline 15 & & & & \\
20 & $1.54^{\mathrm{d}}$ & $1.18^{\mathrm{c}}$ & $1.59^{\mathrm{e}}$ & $0.7^{\mathrm{c}}$ \\
25 & $3.31^{\mathrm{c}}$ & $3.34^{\mathrm{b}}$ & $2.97^{\mathrm{c}}$ & $1.3^{\mathrm{c}}$ \\
30 & $4.73^{\mathrm{a}}$ & $4.53^{\mathrm{a}}$ & $4.13^{\mathrm{b}}$ & $3.96^{\mathrm{ba}}$ \\
35 & $4.02^{\mathrm{b}}$ & $4.38^{\mathrm{a}}$ & $4.63^{\mathrm{a}}$ & $4.18^{\mathrm{a}}$ \\
CV\% & $1.69^{\mathrm{d}}$ & $1.39^{\mathrm{c}}$ & $2.2^{\mathrm{d}}$ & $3.36^{\mathrm{b}}$ \\
LSD & 2.08 & 2.08 & 2.08 & 2.08 \\
\hline
\end{tabular}

Means with the same letter along the column are not significantly different at $\mathrm{P}=0.05$ Rigidoporus isolates showed the best colony growth at $25^{\circ} \mathrm{C}$ and Fusarium isolates were best grown at $30{ }^{\circ} \mathrm{C}$. Lower temperatures like $15^{\circ} \mathrm{C}$ and higher temperatures as $35^{\circ} \mathrm{C}$ were not favourable for the growth of both $R$. microporus and $F$. solani isolates.

\section{Determination of Cross Infection Ability of The Fungal Pathogens Isolated from Jak}

Lesion length appeared along the inoculated root pieces of different host plants by the four different fungal isolates are given in Table 6 . When the root pieces were split longitudinally, discolored area was observed and it was measured as the lesion length. 
Table 6. Lesion length shown by R.microporus isolates and Fusarium isolates on root pieces of different host plants, five days afterinoculation.

\begin{tabular}{|c|c|c|c|c|}
\hline \multirow[b]{2}{*}{ Host plant } & \multicolumn{4}{|c|}{ Mean length of the lesion $(\mathrm{cm})$} \\
\hline & $\begin{array}{l}\text { R.microporusS } \\
\text { EG1 }\end{array}$ & $\begin{array}{l}\text { R.microporus } \\
\text { PM52 }\end{array}$ & F. solani & F.oxysporum \\
\hline Artocarpus nobilis & $4.42^{\mathrm{a}}$ & $5.22^{\mathrm{a}}$ & $5.28^{\mathrm{a}}$ & $4.2^{\mathrm{a}}$ \\
\hline Artocarpus altilis & $3.42^{\mathrm{b}}$ & $3.64^{\mathrm{b}}$ & $3.54^{\mathrm{b}}$ & $3.68^{\mathrm{ba}}$ \\
\hline Hevea brasiliensis & $3.46^{\mathrm{b}}$ & $3.86^{\mathrm{b}}$ & $3.96^{\mathrm{b}}$ & $3.34^{\mathrm{b}}$ \\
\hline $\begin{array}{l}\text { Cinnammomum } \\
\text { zeylanicum }\end{array}$ & $3.38^{\mathrm{b}}$ & $3.62^{b}$ & $3.7^{\mathrm{b}}$ & $3.3^{\mathrm{b}}$ \\
\hline Durio zibethinus & $3.51^{\mathrm{b}}$ & $3.68^{b}$ & $2.94^{\mathrm{cb}}$ & $4.14^{\mathrm{a}}$ \\
\hline Psidium guajava & $2.76^{\mathrm{cb}}$ & $2.58^{\mathrm{cd}}$ & $3.67^{\mathrm{b}}$ & $3.16^{\mathrm{b}}$ \\
\hline Nephellium lapaceum & $2.56^{\mathrm{c}}$ & $2.02^{\mathrm{ed}}$ & $2.36^{\mathrm{cd}}$ & $3.54^{\mathrm{ba}}$ \\
\hline Persea americana & $1.48^{\mathrm{d}}$ & $1.32^{\mathrm{e}}$ & $1.64^{\mathrm{d}}$ & $1.87^{\mathrm{c}}$ \\
\hline $\mathrm{CV} \%$ & 2.03 & 2.03 & 2.03 & 2.03 \\
\hline LSD & 0.73 & 0.93 & 1.02 & 0.83 \\
\hline
\end{tabular}

Means with the same letter along the column are not significantly different at $\mathrm{P}=0.05$

A.nobilis (Wal del) showed the highest mycelia growth of all four isolates, indicating it as a highly susceptible host for all the fungal pathogen isolates tested. In addition, D.zibethinuswas highly infectious for F.oxysporum (Table 6). In comparison to $A$. nobilis, A. altilis, H.brasiliensis and C. zeylanicumare less susceptible to all four fungal pathogen isolates. Among all the tested host plants, P.americana was the least susceptible to all four fungal isolates. Except for F.oxysporum, N.lapaceum showed less susceptibility to $R$. microporus isolates and $F$. solani.

\section{DISCUSSION}

Present study identified four soil borne fungal pathogens (i.e. two isolates of $R$. microporus, $F$. solani and $F$. oxysporum) in root rot-infected Jak trees and determined the effect of selected microenvironmental factors on the colony growth of the pathogens and their cross inflectional ability on several other perennial fruit trees. $R$. microporus has been reported as the white root disease causal agent of a wide range of perennial crops, namely $H$. brasiliensis, A. nobilis, Mucuna bracteata, Camellia sinensis, Cinnamomum zeylanicum, Alstonia macrophylla, Murraya koenigii, Coconut, Jak, Mango, Cashew nuts, Carambola, Avocado, Cassava,Cocoa, Yams, Weeping willows, Teak, Ficus religiosa and Mesua ferrea (Madushani et al., 2013; Madushani et al., 2014; Fernando et al., 2012; Fernando et al., 2016). However, involvement of $F$. solani and $F$. oxysporum as the pathogens of root rot diseases of Jak has not been reported earlier. Further, the present study revealed the presence of $R$. microporus isolates with genetic variations. Isolate SEGI gave the homology to a Malaysian $R$. microporus isolate with a $88 \%$ query cover, 0.00 E-value and $99 \%$ identity. The other isolate, has shown 0.00 E-value and a $99 \%$ identity to a Thailand 
isolate (PM52), but with a $30 \%$ query cover. Oghenekaro et al. (2014) have analyzed molecular variation of $R$. microporus isolates using ITS, LSU, $\beta$-tubulin and translation elongation factor $1-\alpha$ (tef1) gene sequences and identified three distinctive clades corresponding to isolates from Africa, Asia and South/Central America. Therefore, Oghenekaro et al. (2014) suggest the possibility of having at least three different species of Rigidoporus causing white root disease in rubber. Kumari et al. (2014) have determined genetic variation, through RAPD-PCR using 15 random primers using $11 R$. microporus isolates infecting rubber which were collected from different locations of Sri Lanka. Molecular cluster analysis has identified two distinct clusters with many sub clusters, though there was no correlation between the 11 isolates and their geographic origin (Kumari et al., 2014). Based on the above background, further investigations at molecular level are needed to confirm the identity at species level of isolate R8 used in this study.Growth and differentiation of Rigidoporus depend on suitable combination of $\mathrm{pH}$ of the culture medium and the nature and the nature of nitrogen and carbon source (Richard and Botton, 1996). Liyanage et al. (1977) reported the effect of $\mathrm{pH}$, temperature and light intensity of several $R$. lignosus (syn. of. $R$. microporus) collected from white root-infected rubber trees from different locations. According to Liyanage et al. (1977), the optimum temperature for the maximum growth of all 11 isolates has been reported as $30{ }^{\circ} \mathrm{C}$. However, the $R$. microporus isolates obtained from Jak trees showed a different scenario, where the PM52 isolate had the highest colony growth at 25 and $30{ }^{\circ} \mathrm{C}$ and SEG1 isolate had the highest colony growth rate at $25^{\circ} \mathrm{C}$. Therefore, the optimum temperature of all $R$. microporus isolates cannot be generalized. It can vary among the isolates obtained from different hosts as well as among isolates obtained from same host.

In the present study the two $R$. microporus isolates from Jak showed different growth responses to $\mathrm{pH}$. SEG1 isolate had the best growth at a range of $\mathrm{pH} 4-8$ and PM52 isolate was best grown at $\mathrm{pH}$ 6. In contrast to the findings of the present study Liyanage et al. (1977) have reported, $\mathrm{pH} 9$ as the best for growth of $11 \mathrm{R}$. microporus isolates, However, one isolate could tolerate low $\mathrm{pH}$ levels. With reference to the effect of light intensity Liyanage et al. (1977) has reported that $R$. microporus isolates from rubber had a better growth under dark. However, the two $R$. microporus isolates of Jak, used in the present study behaved differently, where SEG1 grew equally well at all light intensities (dark, normal and diffused) but PM52 grew best under normal and diffused light. According to Fayzalla et al. (2008), an isolate of F. oxysporum f.sp. lycopersici and $F$. solani causing wilt and root rot of solanaceous crops have grown best under continuous light, though one isolate of $F$. oxysporum $\mathrm{f}$. sp. lycopersici induced growth under continuous darkness. In contrast to the Fusarium isolates used in our study, which had the best colony growth around $\mathrm{pH} 4-6, F$. oxysporum and $F$. solani causing wilt and root rot of solanaceous crops have grown best at $\mathrm{pH} 8-9$. Effect of $\mathrm{pH}$ on sporulation, production of macro and micro conidia and chlamydospores of Fusarium oxysporumhas been reported by Tyagi and Paudel (2014). Findings of the study revealed valuable information on cross-infectional ability of the four fungal pathogens on perennial trees. All four fungal isolates of Jak are highly infectious on A. nobilis and least infectious on P.americana. The rest of the tested perennial trees 
are equally susceptible to the four fungal isolates of Jak. In addition to that cultures obtained from symptomatic roots of rubber and cinnamon were confirmed as Rigidoporus microporus in gel plate 1. Previous studies by Madushani et al. (2013) have shown that $R$. microporus isolates obtained from several trees such as Mucuna bracteata, Camellia sinensis, Cinnamomum zeylanicum, Artocarpus nobilis, Alstonia macrophylla are infectious to rubber. Therefore, cultivating the perennial trees used in the study, along with Jak pauses a threat and leaving the stumps of those trees provide inocula for Jak. Based on this study Artocarpus nobilis, had a high cross infection rate with white root pathogen in Jak and moderate infection rate with Artocarpus altilis, Cinnamom zeylanicum and Durio zibethinus. Therefore it should not to be advised to cultivate Jak with stumps remaining soils of white root infectious trees of bread fruit, rubber, cinnamon and durian.

\section{CONCLUSIONS}

Two isolates of $R$. microporus, $F$. oxysporum and $F$. solani were identified as pathogens responsible for root rot diseases of jak. Colony growth responses of the above fungal isolates to $\mathrm{pH}$, temperature and light intensity were different among the isolates belonging to the same genera and/or species, indicating inter- and intra species variations of the causal pathogens to the selected microenvironmental factors, hence and influence on fungal colonization. All four fungi were infectious on the tested perennial crops being A. nobilis the most susceptible and P.americana the least susceptible.

\section{REFERENCES}

Arnold, A.E. and Lutzoni, F.(2007). Diversity and host range of foliar fungal endophytes: are tropical leaves biodiversity hotspots?.Ecology.88(3),541-549.

Borines, L.M., Palermo, V.G., Guadalquiver, G.A., Dwyer, C., Drenth, A., Daniel, R. and Guest, D.I.(2014). Jackfruit decline caused by Phytophthora palmivora (Butler).Australas.Plant Pathol.43(2), 123-129.

El-Sayed A. Fayzalla, Yasser M. Shabana and Nasser S. Mahmoud, (2008).Effect of Environmental Conditions on Wilting and Root Rot Fungi Pathogenic to Solanaceous Plants.Plant Pathol. J.7, 27-33.

Fernando, T.H.P.S., Jayasinghe, C.K., Wijesundera, R.L.C. and Siriwardene, D.(2012).Development of an early detection method for white root disease caused by Rigidoporus microporus. Proceedings of International Forestry and Environment Symposium, University of Sri Jayawardhanapura.17.

Fernando, T.H.P.S., Seneviratne, P., Siriwardane, D. and Madushani, H.K.I. (2016). White root disease of Murraya koenigii from Sri Lanka caused by Rigidoporus microporus. J.Natl.Sci.Found. Sri.44 (3), 347-348. 
Kumari, K.A.S.I., Fernando, T.H.P.S. and Balasuriya, A. (2014). Morphological and Genetic Variation of Rigidoporus microporus Isolates from Hevea brasiliensis. Proceedings of the 6th Annual Research Symposium, Rajarata University of Sri Lanka.79.

Liyanage, G.W. Liyanage, A de S., Peries, O.S. Halangoda, L. (1977).Studies on the variability and pathogenicity of Rigidoporus lignosus, Jl. Rubb. Res. Inst. Sri Lanka.54,363-372.

Madushani, H.K.I., Fernando, T.H.P.S., Wijesundara, R.L.C. and Siriwardane, D.(2013). Isolation of Rigidoporus microporus, the cause of WRD of rubber, from some forest associated plants. Proceedings of International Forestry and Environment Symposium.18, 85.

Madushani, H.K.I., Fernando, T.H.P.S., Wijesundara, R.L. andSiriwardane, D. (2014). First report of white root disease of Artocarpus nobilis in Sri Lanka caused by Rigidoporus microporus.J.Natl.Sci.Found. Sri.42(2), 197-198.

Nair, P.N., Palanivel, H. and Kumar, R. (2018).Jackfruit (Artocarpus heterophyllus), a versatile but underutilized food source, Fiji Agriculture Journal, 57 (1), 5-18.

Oghenekaro, A.O., Miettinen, O., Omorusi, V.I., Evueh, G.A., Farid, M.A., Gazis, R. and Asiegbu, F.O.(2014). Molecular phylogeny of Rigidoporus microporus isolates associated with white rot disease of rubber trees (Hevea brasiliensis). Fungal Biol.118(5-6), 495-506.

Richard, T. and Button, B.(1996).Growth and mycelial strand production of Rigidoporus lignosus with various nitrogen and carbon sources. Mycopathologia, 134(2), 83-89.

TRI, M.V., Van Hoa, N., Minh Chau, N., Pane, A., Faedda, R., De Patrizio, A., Schena, L., Olsson, C.H., Wright, S.A., Ramstedt, M. and Cacciola, S.O.(2015). Decline of jackfruit (Artocarpus heterophyllus) incited by Phytophthora palmivora in Vietnam. PhytopatholMediterr.14, 275-280.

Tyagi, S. and Paudel, R.(2014). Effect of different $\mathrm{pH}$ on the growth and sporulation of Fusarium oxysporum: the causal organism of wilt disease of tomato. International Journal of Basic and Applied Biology (IJBAB).2(1), 103-106.

White,T.J., Bruns,T., Lee,S and Taylor,J. (1990). Amplification and direct sequencing of fungal ribosomal DNA for phylogenetics. In: M.A.Innes, D.H. Gelfand, J.J. Sninsky, T. J. White (eds) PCR protocols:a guide to methods and applications. Academic.SanDiego. CA. pp 315-322. 